\title{
Transatlantica
}

Revue d'études américaines. American Studies Journal

$1 \mid 2017$

Morphing Bodies: Strategies of Embodiment in

Contemporary US Cultural Practices

\section{Poetry Books in Multiple Versions: Editorial, Critical, and Pedagogical Issues}

Friday, $29^{\text {th }}$ September 2017, Maison de la Recherche

\section{Bastien Goursaud}

\section{(2) OpenEdition \\ Journals}

\section{Electronic version}

URL: https://journals.openedition.org/transatlantica/8782

DOI: 10.4000/transatlantica.8782

ISSN: $1765-2766$

Publisher

Association française d'Etudes Américaines (AFEA)

\section{Electronic reference}

Bastien Goursaud, "Poetry Books in Multiple Versions: Editorial, Critical, and Pedagogical Issues",

Transatlantica [Online], 1 | 2017, Online since 29 November 2018, connection on 25 May 2021. URL:

http://journals.openedition.org/transatlantica/8782 ; DOI: https://doi.org/10.4000/transatlantica.8782

This text was automatically generated on 25 May 2021.

\section{(c) $(1) \&$}

Transatlantica - Revue d'études américaines est mise à disposition selon les termes de la licence Creative Commons Attribution - Pas d'Utilisation Commerciale - Pas de Modification 4.0 International. 


\section{Poetry Books in Multiple Versions: Editorial, Critical, and Pedagogical Issues}

Friday, $29^{\text {th }}$ September 2017, Maison de la Recherche

\section{Bastien Goursaud}

1 This one day conference was organized as part of a three-year research program led by the Observatoire du Recueil Poétique (ORPo) on "Poetry Books in the Digital Age". It was endorsed by VALE, LARCA and Labex OBVIL, and was organized by Juliette Utard, Aurore Clavier and Gwen Le Cor. The conference looked at "Poetry Books in Multiple Versions" from an editorial, critical and pedagogical perspective.

Isabelle Alfandary argued in her keynote address that, while being central to the poet's strategy for the renewal of American poetry, ungrammaticality in E. E. Cummings' No Thanks is also a major pedagogical tool. It endows the poem with a speculative quality that teaches students to be self-reliant in their analysis. Through the surprise created by Cummings' typographical experiments, the arbitrariness of the sign becomes selfevident. Isabelle Alfandary then showed that the addition of an introduction to the text in academic editions of the poem deprived the reader of its poetics of surprise by elucidating and "re-capitalizing" the experience. Whilst recognizing the academic value of Richard S. Kennedy's introductory attempt at interpreting the structure of No Thanks, Isabelle Alfandary suggested that it disrupted the order of the poem. She added that it failed to account for the tensions between seeing and reading, or between our expectation of the whole and its disjunction by the locality of the poem. Such conflict between academic writing and its object questions our need to make sense of a surprising collection such as No Thanks. Isabelle Alfandary concluded that a long experience of teaching Cummings has made it clear to her that these poems, with their 
emphasis on craftsmanship and typography, are about teaching their readers that they have the keys.

3 At the core of Heather Cass White's paper was the difficulty to define what a poem is. As the editor of Marianne Moore's poetry both in print and in a digital archive, she explained the problems of being faced with numerous complex editorial and critical choices. Throughout her life Moore rewrote old poems, often in shorter versions and with different titles. She also dropped many poems from her oeuvre, which has had critical and pedagogical consequences: some poems have been ignored by critics and in the classroom, and only certain versions of her poems have been taught and studied. Which is why, as the editor of Moore's New Collected Poems, Heather Cass White chose to introduce variant material at the end of the book while she acknowledged a certain "pragmatism" regarding the choice of the poems themselves. The question she therefore asked herself was: what poems should a student or curious reader not miss?

4 Her involvement in the digital archiving of Moore's work, including her notebooks, posed a different challenge altogether. She said that she was concerned that the potentially unlimited space allowed by the digital archive might result in a fetishism of the physical/textual scholarship, which might in turn end up hiding the poetry itself. According to her, such swelling of the paratextual canon also tends to make the critics and users of the archive forget that annotations and biographical information are always modes of interpretation. For her, the appearance of neutrality in editorial work is always suspicious. Instead, she chose to advocate for an archive that merely gave access to "what the poet did".

5 Bart Eeckhout's paper focused on the editorial, critical and pedagogical challenges posed by the proliferating versions of Wallace Stevens's The Man with the Blue Guitar (both the book and the title poem). Always interrogating the pedagogical value of the versions he discussed, Bart Eeckout set out to examine the different ways in which especially the title poem was integrated in selected, collected, and artistically augmented volumes for the English-speaking market, as well as in books of translation. He highlighted a history of publication that was characterized by continuous material change brought to the presentation of the poems, as well as permutations within the architecture of the collection. He concluded by suggesting that such a history of metamorphosis was in keeping with the poem's-and Stevens's-aesthetics of endless and open variation.

6 Julie Blake's talk was on school poetry anthologies designed for fourteen to sixteenyear-olds in England. Focusing on the example of Sylvia Plath's poetry, Julie Blake proposed a history of her inclusion in the national curriculum. Grounding her argument in the work of British socio-linguist Basil Bernstein, she looked at what poems were selected and, more importantly, how they were recontextualised for the classroom by the anthologies. She thus showed that, while certain poems are easily recontextualised and get "pedagogical wings", others remain ignored because they don't seem to be adapted for classroom purposes. She concluded by saying that the British school system's attitude to poetry and its recontextualisation evidenced a particularly keen and lasting desire to control and police what students and teachers should do with the poems.

7 In the final paper of the conference, Chloe Thomas looked at American poet Lyn Hejinian's work My Life and My Life in the Nineties. This autobiographical collection was published in three consecutive versions. Chloé Thomas first explained that Hejinian's 
additions from the first to the second version were seamless, which essentially made the second version an expansion of the first. The final version, published by Wesleyan University Press, only contains the second and third versions. Chloé Thomas argued that the plural and open-ended nature of the poem therefore created several editorial and pedagogical possibilities. She suggested that Hejinian's additions made an online version of the text particularly relevant-it could indeed highlight the additions while preserving their "seamless" quality. She also explained that teaching My Life with its additions might lead to a fruitful emphasis on two key aspects of its poetics: first, an increased sense of the centrality of parataxis and secondly, an insistence on the openended nature of the poem as an autobiographical narrative. In the final part of her talk, Chloé Thomas advocated the idea that a digital edition need not necessarily be restricted to an archival function. Instead, she suggested that the digital version of Hejinian's poem could be construed as a way to work with the blanks of the poemsomething which she called "an exercise in creative reading".

The conference ended on a workshop centered on two different digital projects.

Julie Blake presented the website that accompanied Poetry by Heart, a national poetry recitation competition open to all pupils and students in England aged between 14 and 18, which she founded with Andrew Motion in 2012. The website was created in parallel with the print version of the anthology of poems selected to be performed in the competition. Julie Blake guided us through its architecture, some of the archived performances and the pedagogical material it provides alongside the poems themselves. She described the long but stimulating process of its creation, which was conducted in collaboration with a graphic designer.

The last speaker was Christophe Schuwey, who introduced us to "Naissance de la critique dramatique", a database of XVIIth century archives. Conceived and designed thanks to a partnership between the universities of Freiburg and Lausanne, it contains more than two thousand texts and excerpts about the theatre, specific performances and plays from that period. After discussing the archive's architecture and the archival work that was needed to build it, Christophe Schuwey emphasized the pedagogical value of the archive as a common object of discussion for students and their teachers.

\section{INDEX}

Subjects: Actualité de la recherche 
AUTHOR

BASTIEN GOURSAUD

Université Paris-Sorbonne 